\title{
Synthesis, Characterization and Charge-Discharge Properties of Layer-Structure Lithium Zinc Borate, $\mathrm{LiZnBO}_{3}$
}

\section{Isao Tsuyumoto, Akihiro Kihara}

Department of Applied Chemistry, College of Bioscience and Chemistry, Kanazawa Institute of Technology Ishikawa, Ishikawa, Japan.

Email: tsuyu@neptune.kanazawa-it.ac.jp

Received January $15^{\text {th }}, 2013$; revised February $17^{\text {th }}, 2013$; accepted March $20^{\text {th }}, 2013$

Copyright (C) 2013 Isao Tsuyumoto, Akihiro Kihara. This is an open access article distributed under the Creative Commons Attribution License, which permits unrestricted use, distribution, and reproduction in any medium, provided the original work is properly cited.

\begin{abstract}
Layer-Structure lithium zinc borate, $\mathrm{LiZnBO}_{3}$, is prepared by a solid state reaction of $\mathrm{LiOH} \cdot \mathrm{H}_{2} \mathrm{O}, \mathrm{ZnO}$, and $\mathrm{H}_{3} \mathrm{BO}_{3}$ at $1000^{\circ} \mathrm{C}$ for $10 \mathrm{~h}$. Highly preferred orientation and a layer-structure are observed in the powder XRD patterns and the SEM images, respectively. The Rietveld analysis indicates a monoclinic unit cell with space group $C 2 / c$, and the lattice parameters are refined as $\mathrm{a}=8.827 \AA, \mathrm{b}=5.078 \AA, \mathrm{c}=6.171 \AA$, and $\beta=118.86^{\circ} . \mathrm{LiZnBO}_{3}$ shows the capacity of 17 $\mathrm{mAh} / \mathrm{g}$ between $1.3 \mathrm{~V}$ and $4.3 \mathrm{~V}$ (vs. $\mathrm{Li} / \mathrm{Li}^{+}$) larger than $\mathrm{ZnO}$.
\end{abstract}

Keywords: Oxide; Borate; Lithium; Zinc; X-Ray Diffraction; Battery

\section{Introduction}

Lithium metal phosphates $\left(\mathrm{LiMPO}_{4}\right)$, lithium metal silicates $\left(\mathrm{Li}_{2} \mathrm{MSiO}_{4}\right)$ and lithium metal borates $\left(\mathrm{LiMBO}_{3}\right)$ have attracted considerable interest as cathode materials of lithium ion battery [1]. $\mathrm{LiFePO}_{4}$ with olivine structure showed the reversible extraction and insertion of lithium at $3.5 \mathrm{~V}$ (vs. Li) [2], and this material has been already put to practical use by some lithium ion battery manufacturers. Analogs of $\mathrm{LiFePO}_{4}$ have been explored extensively by many researchers, and the charge-discharge properties have been reported for lithium metal phosphates such as $\mathrm{LiMnPO}_{4}, \mathrm{LiCoPO}_{4}$ [3-5], lithium metal silicates such as $\mathrm{Li}_{2} \mathrm{FeSiO}_{4}$ [6-9], and lithium metal borates such as $\mathrm{LiMnBO}_{3}, \mathrm{LiFeBO}_{3}$ [10-15]. Polyanions with strong covalent bonds such as $\mathrm{PO}_{4}^{3-}, \mathrm{SiO}_{4}^{4-}, \mathrm{BO}_{3}^{3-}$ raise transition metal redox energies through inductive effect and stabilize the structure, thereby providing high performance and chemical safety.

$\mathrm{LiZnBO}_{3}$ was first reported by Lehman and Shadow, and its preparation and characterization have been reported by a number of researchers [16-20]. In the ternary system of $\mathrm{Li}_{2} \mathrm{O}-\mathrm{ZnO}-\mathrm{B}_{2} \mathrm{O}_{3}$, two polymorphs of $\mathrm{LiZnBO}_{3}$ have been reported: one prepared by solid state reaction $\left(\alpha-\mathrm{LiZnBO}_{3}\right)$ and the other from hydrothermal synthesis
$\left(\beta\right.$-LiZnBO $\left.{ }_{3}\right)$. Zinc-containing borates have been investigated aiming at the application to nonlinear optics and ferroelectrics, and the earlier reports describe the preparation of single crystals and structure analysis with a view to non-centrosymmetry. The crystal structure of $\alpha$ $\mathrm{LiZnBO} 3$ is composed of $\mathrm{ZnO}_{4}$ tetrahedra and $\mathrm{BO}_{3}$ triangles by sharing $\mathrm{O}$ vertices and affords three-dimensional open channels that are occupied by lithium ions [20]. In spite of the attractive framework structure of $\mathrm{LiZnBO}_{3}$, there have been no reports on the lithium deinsertion/insertion properties of $\mathrm{LiZnBO}_{3}$. In this study, we successfully synthesized a layer-structure lithium zinc borate, $\alpha-\mathrm{LiZnBO}_{3}$, by a conventional solid state reaction, and investigated its crystal structure, morphology, and lithium deinsertion/insertion properties.

\section{Experimental}

\subsection{Synthesis}

$\alpha-\mathrm{LiZnBO}_{3}$ was synthesized from a stoichiometric mixture of lithium hydroxide, zinc oxide, and boric acid, i.e., $2.10 \mathrm{~g} \mathrm{LiOH} \cdot \mathrm{H}_{2} \mathrm{O}, 4.07 \mathrm{~g} \mathrm{ZnO}$, and $3.09 \mathrm{~g} \mathrm{H}_{3} \mathrm{BO}_{3}$. The mixture was placed in an alumina boat and heated in air at $1000^{\circ} \mathrm{C}$ for $10 \mathrm{~h}$ to yield a white powder product. In earlier reports, polycrystalline $\mathrm{LiZnBO}_{3}$ has been ob- 
tained by heating the stoichiometric mixture of $\mathrm{ZnO}$ and $\mathrm{LiBO}_{2}$ at $1000^{\circ} \mathrm{C}$ for $12 \mathrm{~h}$. After preliminary heating at $620^{\circ} \mathrm{C}$ for $1 \mathrm{~h}$ [19] or by heating the stoichiometric mix-

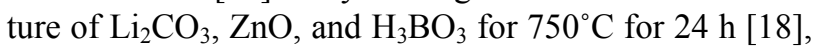
whereas single plate-like crystal of $\alpha$ - $\mathrm{LiZnBO}_{3}$ has been obtained in a lithium borate matrix by heating the mixture of $\mathrm{Li}_{2} \mathrm{CO}_{3}, \mathrm{ZnO}$, and $\mathrm{H}_{3} \mathrm{BO}_{3}$ with excess amount of $\mathrm{Li}_{2} \mathrm{~B}_{4} \mathrm{O}_{7}$ at $830^{\circ} \mathrm{C}$ [20]. In this study, $\mathrm{LiOH} \cdot \mathrm{H}_{2} \mathrm{O}$ was used as the starting material instead of $\mathrm{Li}_{2} \mathrm{CO}_{3}$, and the heating temperature was set at $1000^{\circ} \mathrm{C}$ because the thermogravimetry and differential thermal analysis (DTA/TG, DTG50, Shimadzu, Tokyo, Japan) of the starting mixture in air showed a broad exothermic peak above around $750^{\circ} \mathrm{C}$.

\subsection{Characterization}

The powder X-ray diffraction (XRD) patterns were measured with a diffractometer (XD-D1, Shimadzu, Tokyo, Japan) using graphite-monochromatized $\mathrm{Cu} \mathrm{K} \alpha$ radiation at $30 \mathrm{kV}$ and $20 \mathrm{~mA}$. The crystalline parameters were refined by the Rietveld method using the RIETAN-2000 program [21]. Impurity peaks were excluded in the refinement. The morphology of $\alpha-\mathrm{LiZnBO}_{3}$ was observed by a scanning electron microscope (SEM, JSM-5610, JEOL, Tokyo, Japan). Each sample was ground with acetylene black and polytetrafluoroethylene (PTFE) binder into paste at a weight ratio of $84: 4: 12$, and the paste mixture was pressed onto a nickel mesh for the lithium deinsertion/insertion measurements. The $\mathrm{Ag} / \mathrm{Ag}^{+}$electrode for non-aqueous solvent (RE-7, ALS Corporation Ltd., Tokyo, Japan) was used as a reference electrode, and natural graphite as a counter electrode. A $1 \mathrm{M} \mathrm{LiClO}_{4} \mathrm{EC} / \mathrm{DEC}$ solution ( $\mathrm{EC}: \mathrm{DEC}=1: 1$ in volume) was used as an electrolyte. The lithium deinsertion/insertion measurements were carried out in the galvanostatic mode in the range between $x=0$ and $x=0.5$, where $x$ is the Li content per formula unit, i.e., $x$ in $\mathrm{Li}_{1-x} \mathrm{ZnBO}_{3}$. The electrochemical capacity of samples $(\mathrm{mAh} / \mathrm{g})$ was evaluated using the weight of the active materials.

\section{Results and Discussion}

White powder products were obtained by the solid state reaction at $1000^{\circ} \mathrm{C}$ for $10 \mathrm{~h}$. The powder XRD pattern of the product and the structure refinement result are shown in Figure 1. The crystal structure was refined on the basis of monoclinic symmetry with space group $C 2 / c$ similarly to $\alpha-\mathrm{LiZnBO}_{3}$ in the earlier work [20], except for some impurity peaks. In the XRD measurements, the powder sample was solidified using glue to make each plane randomly oriented, because without the sample pretreatment with the glue the strongest (002) reflection was more than twenty times greater than the second strongest reflection due to the preferred orientation. This suggested that plate-like crystallites were formed by ani-

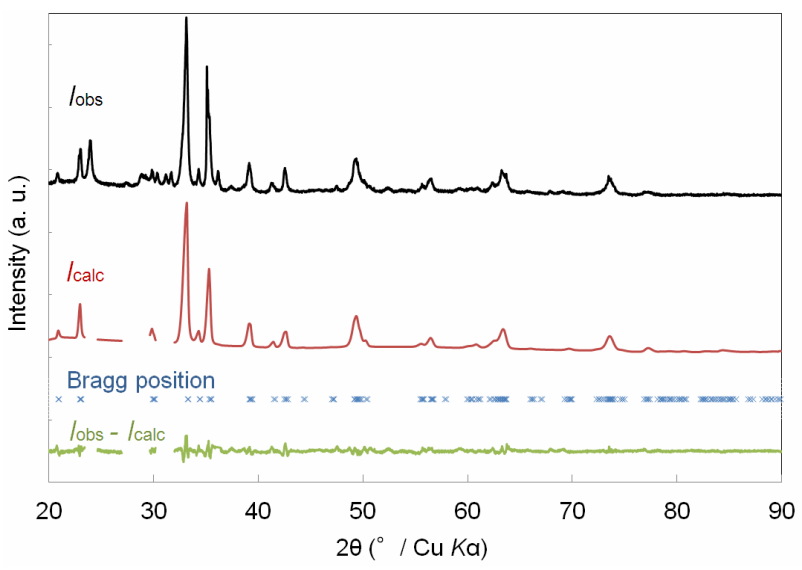

Figure 1. The observed XRD pattern $\left(I_{\mathrm{obs}}\right)$ of the $\mathrm{LiZnBO}_{3}$ and the pattern refined by the Rietveld method $\left(I_{\text {calc }}\right)$, along with the calculated Bragg position and the residual error $\left(I_{\text {obs }}-I_{\text {calc }}\right)$.

sotropic crystal growth and the samples were prone to orient along the $a-b$ plane. Structure parameters and selected interatomic distances are summarized in Tables 1 and 2, respectively, and view of the crystal structure of $\mathrm{LiZnBO}_{3}$ is shown in Figure 2. The lattice parameters and monoclinic angle were calculated as $\mathrm{a}=8.827 \AA, \mathrm{b}=$ $5.078 \AA, \mathrm{c}=6.171 \AA$, and $\beta=118.86^{\circ}$. In this structure, two $\mathrm{ZnO}_{4}$ tetrahedra are linked together by edge- sharing (two $\mathrm{O} 1$ atoms) to form a $\mathrm{Zn}_{2} \mathrm{O}_{6}$ dimer, and the $\mathrm{Zn}_{2} \mathrm{O}_{6}$ dimer is linked to the six other $\mathrm{Zn}_{2} \mathrm{O}_{6}$ dimers by sharing oxygen vertices to form a three-dimensional framework. Boron atoms are located at the triangular void surrounded by three oxygen vertices to form $\mathrm{BO}_{3}$ triangles. Lithium atoms are located in the three-dimensional channels surrounded by $\mathrm{Zn}_{2} \mathrm{O}_{6}$ dimers and $\mathrm{BO}_{3}$ triangles. In this study the $\mathrm{O}_{2}$ atom was located at $8 \mathrm{f}$ site with occupancy of 0.5 , while it was located at $4 \mathrm{e}$ site $(0, \mathrm{y}, 1 / 4)$ with occupancy of 1.0 in the earlier work [20]. The two $\mathrm{O}_{2}$ atoms with each occupancy of 0.5 were refined at extremely close two positions at the vertex of $\mathrm{ZnO}_{4}$ tetrahedron, as shown in Figure 2, indicating the two possibilities of $\mathrm{ZnO}_{4}$ tetrahedron shape. Such arbitrary property is probable in view of the occupancy of 0.5 for $\mathrm{Zn} 1$. In Figure 3, SEM images show secondary particles formed by aggregation of plate-like crystallites, and the crystallites are considered to be stacked perpendicular to the a-b plane. The present sample showed a lamellar structure consisting of plate-like crystallites stacked perpendicular to the $a-b$ plane. This may be advantageous to lithium deinsertion/insertion because open channels in the crystallites are facing the electrolyte with large area. The conductivity of the powder compact of the present $\mathrm{LiZnBO}_{3}$ estimated from the diameter of the semicircle in the cole-cole plot was $2.12 \times 10^{-9} \mathrm{Scm}^{-1}$. It is much smaller than $\mathrm{LiFeBO}_{3}, 1.52 \times 10^{-4} \mathrm{Scm}^{-1}$ [12], and as small as $\mathrm{LiFePO}_{4}, 2.2 \times 10^{-9} \mathrm{Scm}^{-1}$ [23]. The low electric 
Table 1. Structure parameters of $\mathrm{LiZnBO}_{3}$ obtained by heating at $1000^{\circ} \mathrm{C}$ for $10 \mathrm{~h}$. System: monoclinic. Space group: $C 2 / c$ (No. 15), $a=8.827 \AA, b=5.078 \AA, c=6.171 \AA ⿻, \beta=$ $118.86^{\circ}, z=4$.

\begin{tabular}{cccccc}
\hline Atom & Site & $x$ & $y$ & $z$ & Occupancy \\
\hline Li1 & 8f & $0.310(4)$ & $0.603(4)$ & $0.797(4)$ & 0.50 \\
Zn1 & 8f & $0.3223(7)$ & $0.567(2)$ & $0.6965(9)$ & 0.50 \\
B1 & $4 \mathrm{e}$ & 0.00 & $0.408(4)$ & 0.25 & 1.0 \\
O1 & 8f & $0.167(1)$ & $0.543(4)$ & $0.295(2)$ & 1.0 \\
O2 & 8f & $0.03(2)$ & $0.172(2)$ & $0.318(2)$ & 0.50 \\
\hline
\end{tabular}

Table 2. Selected interatomic distances $(\AA)$ of $\mathrm{LiZnBO}_{3}$.

\begin{tabular}{cccc}
\hline Selected atom & Distance $(\AA)$ & Selected atom & Distance $(\AA)$ \\
\hline Li1-O1 & $1.46(4)$ & Li1-O1 & $1.93(3)$ \\
Li1-O2 & $2.13(3)$ & Li1-O2 & $2.31(3)$ \\
Li1-O2 & $2.36(3)$ & & \\
Zn1-O1 & $1.84(1)$ & Zn1-O1 & $1.98(2)$ \\
Zn1-O1 & $2.18(1)$ & Zn1-O2 & $1.85(2)$ \\
Zn1-O2 & $1.99(2)$ & & \\
B1-O1 & $1.52(1)$ & B1-O2 & $1.25(9)$
\end{tabular}
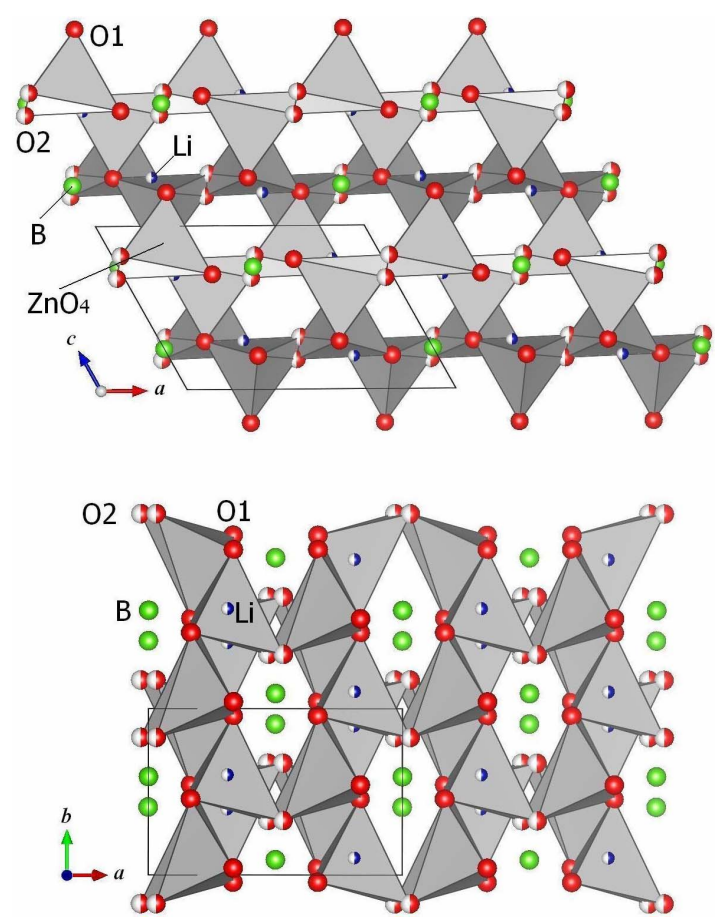

Figure 2. The crystal structure of the $\mathrm{LiZnBO}_{3}$ projected along b-axis (upper) and c-axis (lower) visualized by VESTA3 [22]. Half-filled and fully-filled circles mean the occupancies of 0.50 and 1.0 , respectively.

conductivity and/or lithium diffusivity suggests the necessity to give conductivity to $\mathrm{LiZnBO}_{3}$ by treatment with carbon in order to improve the electrochemical

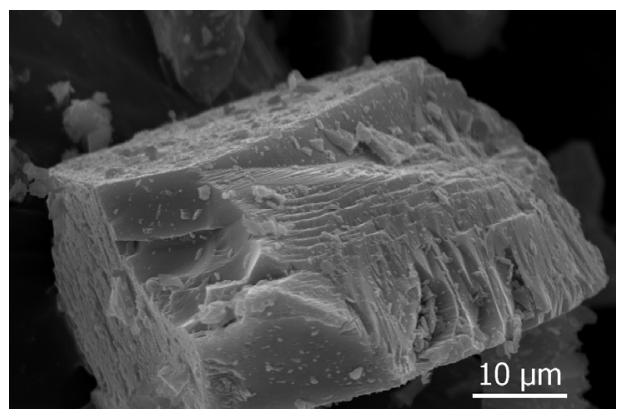

Figure 3. The SEM image of the layer-structure $\mathrm{LiZnBO}_{3}$. The plane facing upward is the a-b plane.

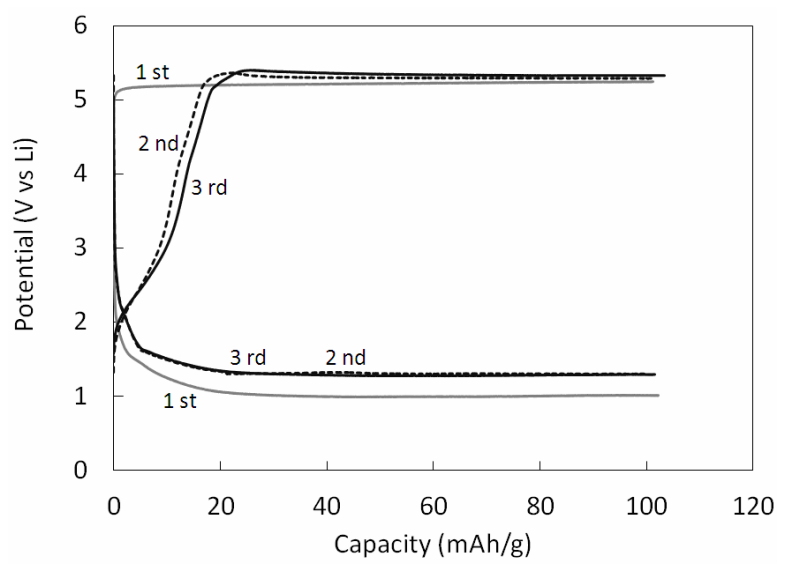

Figure 4. The charge-discharge curves of the $\mathrm{LiZnBO}_{3}$ for first three cycles at rate of $20.3 \mathrm{~mA} / \mathrm{g}$.

performance.

Figure 4 shows the typical charge and discharge curvesof $\mathrm{LiZnBO}_{3}$ at charge/discharge rate of $20.3 \mathrm{~mA} / \mathrm{g}$. The first charge curve deviated from the second and third ones, indicating that the solid electrolyte interface (SEI) was formed at the cathode/electrolyte interface during the first charge process. The capacity between $1.3 \mathrm{~V}$ and 4.3 $\mathrm{V}$ (vs. $\mathrm{Li} / \mathrm{Li}^{+}$) was $17 \mathrm{mAh} / \mathrm{g}$, and the charge/discharge curves showed almost the same behavior for different charge/discharge rates from $2.03 \mathrm{~mA} / \mathrm{g}$ to $203 \mathrm{~mA} / \mathrm{g}$. It should be noted that our comparative experiments using $\mathrm{ZnO}$ as an active material did not show such charge/discharge behavior. This is probably because $\mathrm{LiZnBO}_{3}$ acted as an electric double layer capacitor (EDLC) and electric charge was accumulated at the interfacial region between the electrolyte and $\mathrm{LiZnBO}_{3}$ powder. The layer structure of $\mathrm{LiZnBO}_{3}$ was advantageous for EDLC over $\mathrm{ZnO}$. The faradaic redox reaction of $\mathrm{LiZnBO}_{3}$ was not observed as opposed to the cases of $\mathrm{LiFeBO}_{3}$ and $\mathrm{LiMnBO}_{3}$ [10-15], indicating that divalent zinc was not oxidized to trivalent zinc in $\mathrm{LiZnBO}_{3}$ as well as in $\mathrm{ZnO}$.

\section{Conclusion}

Lithium zinc borate, $\mathrm{LiZnBO}_{3}$, prepared by the solid state reaction showed a layer-structure in the SEM images. 
The XRD patterns well fitted to a monoclinic unit cell with space group $C 2 / c$, and the lattice parameters were refined as $\mathrm{a}=8.827 \AA, \mathrm{b}=5.078 \AA, \mathrm{c}=6.171 \AA$, and $\beta=$ $118.86^{\circ}$. $\mathrm{LiZnBO}_{3}$ showed the capacity of $17 \mathrm{mAh} / \mathrm{g}$ between $1.3 \mathrm{~V}$ and $4.3 \mathrm{~V}$ (vs. $\mathrm{Li} / \mathrm{Li}^{+}$) larger than $\mathrm{ZnO}$. The capacity was due to the EDLC between the electrolyte and $\mathrm{LiZnBO}_{3}$ powder.

\section{REFERENCES}

[1] B. L. Ellis, K. T. Lee and L. F. Nazar, "Positive Electrode Materials for Li-Ion and Li-Batteries," Chemistry of Materials, Vol. 22, No. 3, 2010, pp. 691-714. doi:10.1021/cm902696j

[2] A. K. Padhi, K. S. Nanjundaswamy and J. B. Goodenough, "Phospho-Olivines as Positive-Electrode Materials for Rechargeable Lithium Batteries," Journal of the Electrochemical Society, Vol. 144, No. 4, 1997, pp. 1188-1194. doi:10.1149/1.1837571

[3] M. Yonemura, A. Yamada, Y. Takei, N. Sonoyama and R. Kanno, "Comparative Kinetic Study of Olivine $\mathrm{Li}_{x} \mathrm{MPO}_{4}$ $(\mathrm{M}=\mathrm{Fe}, \mathrm{Mn})$," Journal of the Electrochemical Society, Vol. 151, No. 9, 2004, pp. A1352-A1356. doi:10.1149/1.1773731

[4] D. Wang, H. Buqa, M. Crouzet, G. Deghenghi, T. Drezen, I. Exnar, N. H. Kwon, J. H. Miners, L. Poletto and M. Grätzel, "High-Performance, Nano-Structured $\mathrm{LiMnPO}_{4}$ Synthesized via a Polyol Method," Journal of Power Sources, Vol. 189, No. 1, 2009, pp. 624-628. doi:10.1016/j.jpowsour.2008.09.077

[5] K. Amine, H. Yasuda and M. Yamachi, "Olivine Li$\mathrm{CoPO}_{4}$ as $4.8 \mathrm{~V}$ Electrode Material for Lithium Batteries," Electrochemical and Solid-State Letters, Vol. 3, No. 4, 2000, pp. 178-179. doi:10.1149/1.1390994

[6] A. Nytén, A. Abouimrane, M. Armand, T. Gustafsson and J. O. Thomas, "Electrochemical Performance of $\mathrm{Li}_{2} \mathrm{Fe}-$ $\mathrm{SiO}_{4}$ as a New Li-Battery Cathode Material," Electrochemical Communications, Vol. 7, No. 2, 2005, pp. 156160. doi:10.1016/j.elecom.2004.11.008

[7] A. Nytén, S. Kamali, L. Häggström, T. Gustafsson and J. O. Thomas, "The Lithium Extraction/Insertion Mechanism in $\mathrm{Li}_{2} \mathrm{FeSiO}_{4}$," Journal of Materials Chemistry, Vol. 16, No. 23, 2006, pp. 2266-2272. doi:10.1039/b601184e

[8] M. Nadherna, R. Dominko, D. Hanzel, J. Reiter and M. Gaberscek, "Electrochemical Behavior of $\mathrm{Li}_{2} \mathrm{FeSiO}_{4}$ with Ionic Liquids at Elevated Temperature," Journal of the Electrochemical Society, Vol. 156, No. 7, 2009, A619A626. doi:10.1149/1.3133183

[9] C. Sirisopanaporn, C. Masquelier, P. G. Bruce, A. R. Armstrong and R. Dominko, "Dependence of $\mathrm{Li}_{2} \mathrm{FeSiO}_{4}$ Electrochemistry on Structure," Journal of the American Chemical Society, Vol. 133, No. 5, 2011, pp. 1263-1265. doi:10.1021/ja109695r

[10] V. Legagneur, Y. An, A. Mosbah, R. Portal, A. Le Gal La Salle, A. Verbaere, D. Guyomard and Y. Piffard, "LiM$\mathrm{BO}_{3}(\mathrm{M}=\mathrm{Mn}, \mathrm{Fe}, \mathrm{Co})$ : Synthesis, Crystal Structure and Lithium Deinsertion/Insertion Properties," Solid State Ionics, Vol. 139, No. 1-2, 2001, pp. 37-46. doi:10.1016/S0167-2738(00)00813-4
[11] Y. Z. Dong, Y. M. Zhao, Z. D. Shi, X. N. An, P. Fu and L. Chen, "The Structure and Electrochemical Performance of $\mathrm{LiFeBO}_{3}$ as a Novel Li-Battery Cathode Material," Electrochimica Acta, Vol. 53 No. 5, 2008, pp. 2339-2345. doi:10.1016/j.electacta.2007.09.050

[12] Y. Z. Dong, Y. M. Zhao, P. Fu, H. Zhou and X. M. Hou, "Phase Relations of $\mathrm{Li}_{2} \mathrm{O}-\mathrm{FeO}-\mathrm{B}_{2} \mathrm{O}_{3}$ Ternary System and Electrochemical Properties of $\mathrm{LiFeBO}_{3}$ Compound," Journal of Alloys and Compounds, Vol. 461, No. 1-2, 2008, pp. 585-590. doi:10.1016/j.jallcom.2007.07.099

[13] A. Yamada, N. Iwane, Y. Harada, S. Nishimura, Y. Koyama and I. Tanaka, "Lithium Iron Borates as High-Capacity Battery Electrodes," Advanced Materials Vol. 22, No. 32, 2010, pp. 3583-3587. doi:10.1002/adma.201001039

[14] J. C. Kim, C. J. Moore, B. Kang, G. Hautier, A. Jain and G. Ceder, "Synthesis and Electrochemical Properties of Monoclinic $\mathrm{LiMnBO}_{3}$ as a $\mathrm{Li}$ Intercalation Material," Journal of the Electrochemical Society, Vol. 158, No. 3, 2011, pp. A309-A315. doi:10.1149/1.3536532

[15] A. Yamada, N. Iwane, S. Nishimura, Y. Koyama and I. Tanaka, "Synthesis and Electrochemistry of Monoclinic $\mathrm{Li}\left(\mathrm{Mn}_{x} \mathrm{Fe}_{1-x}\right) \mathrm{BO}_{3}$ : A Combined Experimental and Computational Study," Journal of Materials Chemistry, Vol. 21, No. 29, 2011, pp. 10690-10696. doi:10.1039/c1jm11131k

[16] H. A. Lehmann and H. Schadow, "Bildung und Darstellung von gemischten Monoboraten des Types $\mathrm{MeLiBO}_{3}$, $(\mathrm{Me}=\mathrm{Co}, \mathrm{Zn}, \mathrm{Mn})$, , Zeitschrift für Anorganische und Allgemeine Chemie, Vol. 348, No. 1-2, 1966, pp. 42-49. doi:10.1002/zaac.19663480106

[17] O. S. Bondareva, M. A. Simonov, Y. K. Egorov-Tismenko and N. V. Belov, "The Crystal Structures of LiZn $\left[\mathrm{BO}_{3}\right]$ and $\mathrm{LiMn}\left[\mathrm{BO}_{3}\right]$," Soviet Physics Crystallography, Vol. 23, No. 3, 1978, pp. 269-271.

[18] A. Belkebir, P. Tarte, A. Rulmont and B. Gilbert, "Synthesis, Structural and Vibrational Analysis of $\mathrm{LiMBO}_{3}$ Orthoborates (M = Mg, Co, Zn)," New Journal of Chemistry, Vol. 20, No. 3, 1996, pp. 311-316.

[19] K. S. Chang, "LiZnBO ${ }_{3}$ : Crystal Structure," Journal of the Korean Chemical Society, Vol. 45, No. 19, 2001, pp. 251255.

[20] X. Chen, C. Yang, X. Chang, H. Zang and W. Xiao, "Syntheses and Characterization of Two Alkali-Metal Zinc Borates, $\alpha$-LiZnBO and $\mathrm{Li}_{0.48} \mathrm{Na}_{0.52} \mathrm{ZnBO}_{3}$," Solid State Sciences, Vol. 11, No. 12, 2009, pp. 2086-2092. doi:10.1016/j.solidstatesciences.2009.08.024

[21] F. Izumi and T. Ikeda, "A Rietveld-Analysis Programm RIETAN-98 and Its Applications to Zeolites," Materials Science Forum, Vol. 321-324, 2000, pp. 198-205. doi:10.4028/www.scientific.net/MSF.321-324.198

[22] K. Momma and F. Izumi, "VESTA 3 for Three-Dimensional Visualization of Crystal, Volumetric and Morphology Data," Journal of Applied Crystallography, Vol. 44, No. 6, 2011, pp. 1272-1276. doi:10.1107/S0021889811038970

[23] D. Wang, H. Li, S. Shi, X. Huang and L. Chen, "Improving the Rate Performance of $\mathrm{LiFePO}_{4}$ by Fe-Site Doping," Electrochimica Acta, Vol. 50, No. 14, 2005, pp. 29552958. doi:10.1016/j.electacta.2004.11.045 